\title{
緒方＼cjkstart章教授の喜寿を記念して
}

本会名誉会員 前会頭 緒方 章教授が本月 26 日をもって喜寿の誕生日を迎兄らるるに当たり, 日本薬学会 は心からの视福を捧げる.

緒方教授の本会員としての活動はすでに半世紀余の長さにわたり，この間本会役員として多年重要会務に参画

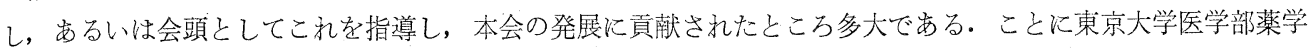

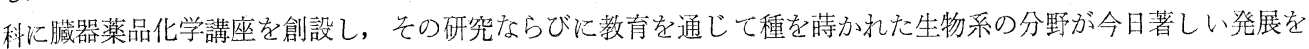
とげ，多彩な実を結ぶにいたったことは万人の認めるところである。また近年は後輩の指導とともに「一粒の麦」

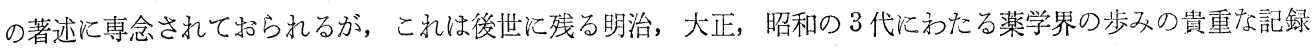
ともなるものである。

ここに日本薬学会は教授の本会に対する多年の功績に深甚の謝意を表するとともに，今後ますます御健康に留 意され，本会の元老として一層の御後援を希う次第である.

昭和 39 年 10 月 26 日

社団法人日本薬学会

会頭津田恭介

\section{緒方 章先生の喜寿に際して}

緒方 章先生は明治 20 年 10 月 26 日 (1887年) 緒方惟準の四男として大阪市で抢生李れになった・緒方家は

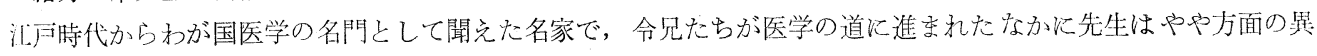
なった，しかしながら医学とさわめて関係の深い薬学の道へ進まれたわけであるが，このことは後に述べるよう に医学, 薬学画分野の御兄弟の協力といら形で学問的にもまた貴重な成果を生むこととなったのである。

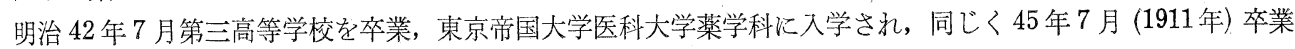

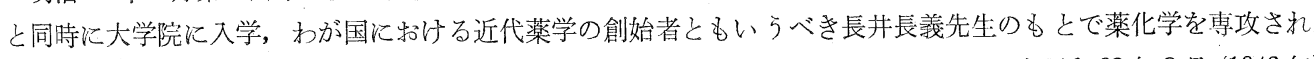
ることとな⿰た。 1 年後の大正 2 年 9 月には東京常国大学医科大学助手に任ぜられ, 以来昭和 23 年 3 月 (1948 年) 東京大学に打ける教授定年制の申し合わせに基ついて退職されるなで 36 年間の長きにわたって大学の職務につく されたのである，その間大正 8 年 (1919年) には『局所麻醉性を有する「アミノ」化合体の構造研究』によって薬 学博士の学位を得られ, 翌大正 9 年 12 月には東京大学助教授に任ぜられている.

当時先生の研究の主なる対象は有機化学の分野に属するものであったが, 後汇東京帝国大学飞臟器薬品化学講 座が設置されるにあたって初代教授化就任され, 引が国の薬学界に扔いて薬理学, 内分泌薬学, 哺乳動物生理化 学の方面で開拓者として活躍されるにいたった片鱗はすでにこの時代かららかがわれるここるであって, アドレ ナリンの組織化学的是色反応や, 局所麻醮性アミノ化合体, 七マシ油酸類似化合体, フェノールフタレイン類似 化合体などの化学構造と生理作用之の関係など生物科学々関連した分野汇る研究の手老下して扰られるのである. 大正 12 年 2 月 (1923 年) には薬化学研究のためドイッ, イギリス, アメリカの各国汇約 1 年間留学されたが, 当時注第一次世界大戦後の学問の一つの発展期であって, ホルモン, ビタミンなど生物科学の分野の発展が著し く,わが国の薬学界でもこれらの方面で内容を充実する必要性が痛感されたので大正 13 年 4 月, 当時東京帝国大学 医学部薬学科の教授, 助教授, 卒業生などが中心となって母学振興期成会 (後汇薬学振興会と改称) が結成され, 腈器薬品化学講座を東京帝国大学汇設置すべく，そのための必要経費を卒業生や関係者から募金して講座を大学 
に寄付することが計画された。このような機運のなかで先生は薬学振興会の推蔗を受けて大正 14 年 2 月ふたた びドイッに留学. ベルリン大学薬理学教室で Joahimoglu助教授とともに 2 年間薬理学の研究に従事された. 帰国 されてのら昭和 5 年 3 月 (1930年) 東京帝国大学教授任ぜられ, 新設された臟器薬品化学講座の初代教授として 新講座の創設整備に努力された，時あたか子わが国に括ける内分泌療法の勃興期に際会しわが国ではじめて内 分泌薬学を創始し，その体系を樹立して後進の指導育成にあたられたばかりでなく，先生自ら男性ホルモン，甲 状腺ホルモン, 睡液腺ホルモンの研究に没頭され, その活躍によってわが国の内分泌学の水準は世界的レベルに まで高められたのである。

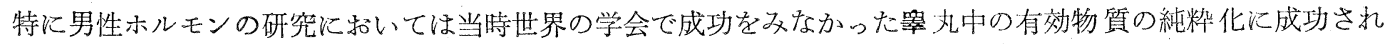
たが，これは当時各国の学者汇よって報告された男性ホルモン作用のある結晶またはエキスのいずれよりる効力 が大なるものであったが惜しいかな材料欠乏のため構造決定にはいたらなかった. 先生によって行なわれたホル モン関する研究のらちで最もニニークなるのは陲液腺ホルモンの研焭であって, これは先生の令兄で東京大学 医学部病理学講座の担任教授であった緒方知三郎博士との協力によって行なわれたものである. 崜液腺になんら かの内分泌機能があるのではないかということはすで前世紀の終り頃から臨床的知見や動物実験の結果から推 論されていたが，緒方知三郎教授によって昭和 3 年（1928 年）頃から行なわれた組織形態学的ならびに実験病理 学的研究の結果, 睡液腺特に耳下腺からは骨や歯のごとさ硬組織の組織形成に必要なホルモンが分泌されている という学説が提出された．この学説は昭和 15 年頃（1940年）までにはほぼままった概念が確立されたが, 緒方 章先生はこの学説に忘觉て動物の耳下腺からこのホルモンを抽出してその実体を明らかにすべく研究を開始され, 間もなく昭和 18 年(1943 年) 骨や歯の形成を維持促進させ, 血清カルシウムを低下させる作用を持ったタンパク 性因子を抽出すること成功され，これに“パチロン”之命名された。 パロチンに関する研究は先生が定年で退 職された後も東京大学薬学部の伊藤四十二教授らによって引継がれ, 臨床医学の全分野をも含めた広汎な研究に まで発展し，老人性骨・軟骨疾患をはじめとする多くの臨床的応用面が開拓されるにいたったのである.

先生の研究は単に内分泌薬学の範囲内に止まるものではなく, 有機化学を基礎として広く生物化学, 楽理学な ど当時の薬学にとっては末ったく新しい分野の開拓につとめられたことが特徵であって，このような色彩の濃い

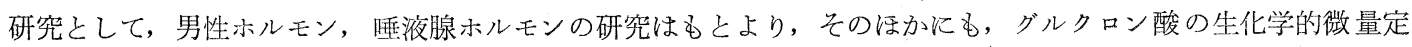
量法, グルクロン酸の生化学的製造法, ヂクタムニンの毒性, 乾燥甲状腺の試験法, ジョードチロシンの生理作 用, 甲状腺ホルモンの検定法, 人工栽培した麦角の効力, ブロムマグネシウムの生理作用, ヂギタリスの効力検

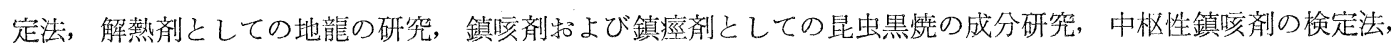
海亀油の成分ならびにその経皮吸収, ベンッヒドリルアミン系化合物の局所麻畹性に関する化学構造と生理作用, 蜔虫駆除薬の試験法，ナフタリン系化合体の駆虫作用などの諸研究をる行なって呿られる．同時になたこのよ5 な学術的研究とならんで，きわめて幼稚であった昭和初期のわが国内分泌治療薬の製造を指導育成されこれによ って内分泌療法学の発達, わが国医療水準の向上飞側面的な笴点をなさった功績も少䄈くない。昭和 23 年 3 月 (1948 年) 定年で東京大学教授を辞された後も睡液腺に関する研究には終始深い関心を笴せておられ, 睡液腺研究 会の副会長, のちに会長 (1961 年より 1964年現在にいたる)として後進を見守って呿られることは屯ことに心強 いことである.

先生は研究者として立派な業績をあげて抢られるばかりでなく，教育者としてもをた常に温容あふれる高い人 格をもって学生, 教室員の指導にあたられた。研究の指導にあたっては実験室を巡回して若い教室員や学生の研 究に適切な指示を与えられるばかりでなく，自ら試験管やフラスコをとって実演のうちに実験法の真䯣を教授さ れるのが常であった．東京大学はこのような先生の教育ならびに研究上の功績に報いるため名誉教授の称号を贈 って炎の功を称完ている。しかしながら直接先生の指導を受けた人々以外飞もその名を師として記憶する人は少

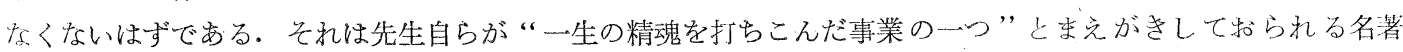
『化学実験操作法』によってである.この書は単温学のみならず化学実験に関係あるすべての分野の研究者, 学生にとってこよなき指導書であり, 相談相手となっている. このことを証明するには大正 14 年 (1925年) 初版 発行以来 5 回にわたって改訂增補, あるいは增巻され, 全 5 巻 1692 頁の大著となり, 昭和 38 年 (1963年) 現在まで 飞寒に 27 版を重ねたととを記するのみで十分である5.

先生は大学飞技いては教育研究の両面で職務につくされたほかに, 学外に呿いては学術研究会議会員, 学術研 
究会議第二部研究班班長として学術の進歩発展に努力され, 西るいはまた文部省視学委員, 薬学教育審議会委員 として薬学教育の改善に心をくだかれ，さらにはをた薬剤師試験委員， 日本薬局方調査会委員敊よび会長，薬剤 師国家試験審議会委員長, 薬事委員会委員長, 薬事審議会会長, 医薬制度調查会委員などの公職を通じて医薬行 政の5えにもつくされた．特薬事委員会 (のらに改称されて薬事審議会となった) に特いては昭和 23 年 10 月

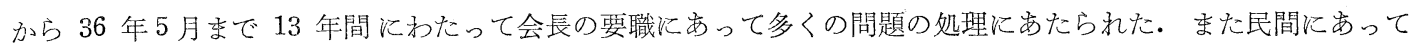
は日本薬剤師協会理事, 副会長, 会長 (昭和 23 年扔よび 29 年) として, 西るいは日本薬学会評議員, 幹事, 副会長 (昭和 15 年度), 会長 (昭和 16 年度拈よび 22,23 年度) として, 来た日本内分泌学会会長 (昭和 23 年度) として広く医, 楽両学界のために寄与された.

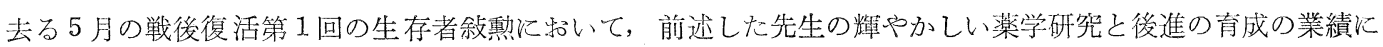
対して 3 号銀盃 (すでに上級勲賞が授与されているため) が授与される栄誉に浴せられたことは誠に麖賀にたえな い次第である.

そしてい先生は自敍伝ともいらべき『一粒の麦』の続編の執筆に多忙の日々を送って招られるが，これによ って明治, 大正, 昭和の 3 代にわたっての日本薬学のあゆみの一面が後世残されることは誠に意義深いことと いうべきである。

(伊藤四十二)

\section{緒方＼cjkstart章博士ならびにその業績}

1. 緒方 章: 伊藤忠治郎 : 薬誌, 36, 209〜232（1916） メチールベンチールケトンの一新製法並びにフェニー ルズルフォナールの合成

2. 緒方 章: 薬誌，36，387３93 (1916) 重クローム酸カリによるアドレナリンの呈色反応について

3. 緒方 章: 薬誌； 36，695〜715（1916）フェニールニトロブタノールアミンの還元成績体について

4. 緒方 章: 薬誌，36，715７20（1916）ベンチールアミン誘尊体について（モノアルキルベンチルアミンの 一新製法)

5. 緒方 章: 薬誌，37，799〜806（1917） アルキール（アリール） ベンチールケトンの合成（第一報）

6. 緒方 章: 薬誌，38，855８61 (1918) アルキールベンチールケトンの合成（第二報）

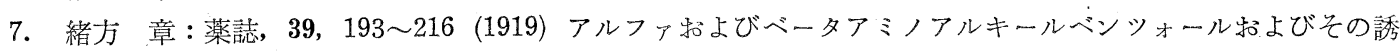
導体について

8. 緒方 章: 薬誌，39，751７65（1919）デスオキシェフェドリンについて（エフェドリンの構造論）

9. 緒方 章: 薬誌， 40， 81～151 (1920) 局所麻酔性を有するアミノ化合体の構造とその生理作用との関係汇 つい,

10. 緒方 章: 宮下忠治 : 薬誌，42，473～482（1922）薄荷脳同属列化合体の合成

11. 緒方 章: 開運隆憲: 薬誌, 43，75８1 (1923) 苛性アルカリの鉛塩に対する反応について

12. 緒方 章: 薬誌，43，81８2（1923）空気中の炭酸湿気などを遮断して汇過する装置

13. 緒方 章：岡崎正敏：薬誌，43，535〜545（1923）化学的構造の腸蠕動に及ぼす関係について (第一報) 菎麻子油酸類似化合体

14. 緒方 章：西大路隆憲：薬誌，44，1040１049（1924）車前子の成分

15. 緒方 章: 近藤 龍: 薬誌, 45，339〜351 (1925) 摘出腸管飞対するフェノールフタレイン類似化合體の作 用について

16. 緒方 章：山内俊雄：薬誌，49，541〜556（1929）グルクロン酸ならびに複合グルクロン酸の定量法（第一 報)

17. 緒方 章: 平野四郎 : 楽誌， 50，555５59（1930） アルデヒドあるいはケトンと带硝酸との混合物の還元 (第一報)ア七トキシウム並びに塩酸ヒドロキシアミンの一新製法 
18. 緒方 章, 山内俊雄 : 薬誌，50，1059１075（1930）グルクロン酸並びに複合グルクロン酸の定量法（第二 報）人尿並びに家鬼尿中のグルクロン酸比色定量法

19. 緒方’章 : 薬誌, 50, 1124〜1133 (1930) ヂクタムニンの毒性試験

20. 緒方 章, 平野四郎 : 薬誌, 50, 1144〜1152（1930) アルデヒド或はケトンと带硝酸との混合物の還元（第 二報) ベンッアルデヒドと亜硝酸の還元

21. 緒方 章, 湊 顕：薬誌，51，946９54（1931）乾燥甲状腺末と炎の検定法に就て

22. 緒方 章, 西大路隆憲: 薬誌, 51，954～958（1931）米国薬局方乾燥甲状腺中のヨード定量法汇対する批判

23. 緒方 章, 大谷文昭: 薬誌, 52, 25 45 (1932) 麦角人工栽培の研究 (大谷文昭) 第 2 報 富山に打いて人 工栽培せる麦角の効価汇就て

24. 緒方 章, 佐野十九一: 薬誌， 52，543〜552（1932）ブロームマグネシウムの生理的作用汇就て (第一報)

25. 緒方，章，伊藤四十二：薬誌， 52，671 673 (1932) 逨続液体抽出器の一新考案に就て

26. 緒方 章, 伊藤四十二 : 薬誌, 52, 674 697 (1932) 男性ホルモンの研究（第一報）男尿中の男性ホルモン (其 1 )

27. 緒方 章, 佐野十九一: 薬誌, 52，746〜755（1932）ブロムマグネシウムの生理的作用に就て（第 2 報）ブ ロムマグネシウムと硫酸マグネシウムとの鎮痙作用の比較

28. 緒方 章, 平野四郎, 平田重雄: 薬誌, 52, 1060 1085（1932）男性ホルモンの研究（第 2 報）墄丸ホルモ ンの研究 (其 1 )

29. 緒方 章, 伊藤四十二 : 薬誌, 53，213～247 (1933) 男性ホルモンの研究（第 3 報）鷄冠の生長に依る男性 ホルモン検定法に就て（其 1 ） 鵎冠測定法批判並びに新測定法

30. 緒方 章, 平野四郎：薬誌, 53, 869 891 (1933) 男性ホルモンの研究（第 4 報）睬丸ホルモンの研究（其 2)

31. 緒方 章, 細井千代馬, 西 光博, 富岡七郎：楽誌，54，280２91 (1934)，タトン或はアルデヒドと亜硝酸 ソーダの混合物の還元（第 3 報）

32. 緒方 章, 平野四郎, 田中真一: 薬誌, 54, 351 357 (1934) 男性ホルモンの研究（第 5 報）鷄冠の生長に 依る男性ホルモン検定法に就て（其 2) 一新鷄単位

33. 緒方 章, 小西真雄: 薬誌, 54，546〜550 (1934) 硝酸試薬としてのヂエチールベンッヒドリールアミンと 就て

34. 緒方 章, 小西真雄, 林 消五郎：楽億，54，550〜557 (1934) モノ及びヂエチルベンッヒドリールアミン に就て〔附. ビノメチルベンッヒドリールアミン及びメトキシベンッヒドリルアミンに就て〕

35. 緒方 章, 平野四郎：楽誌，54，1010１019（1934）男性ホルモンの研究（第6 報） 辠丸ホルモンの研究（其 3 ）一新結晶男性ホルモン

36. 緒力 音, 平野四郎 : 薬誌, 54, 1068 1072（1934）男性ホルモンの研究（第 7 報） 去勢ラッテ精囊重量增加に依る男性ホルモンの検定法 一新ラッテ単位

37. 緒方 章, 田中時彦: 薬誌, 55, 46〜54 (1935) Dijodotyrosin の生体汇対する作用に就て (其 1) 利尿作 用

38. 緒方 章, 新延信吉: 薬誌, 56, 497〜510 (1936) Benzhydrylamin 及び Benzyl-phenäthylamin 系化合 体の局所麻枠性と構造との関係化就て (第 1 報)

39. 田中時彦，緒方 章：薬誌，56，779～801 (1936) Dijodotyrosin の生体に対する作用飞就て (其 2) 毒力, 循環系臓器, 平滑筋歲器及び女性性殖腺に及洔す影響

40. 緒方 章, 由中時彦: 薬誌, 57, 541 547 (1937) ヂギタリス力価検定法もしてり Focke 法と Uhlmann 法 の比較

41. 緒方 章, 西川正元 : 薬誌, 57，1053 1058（1937）グルクロン酸の製法汇就て（第 1 報）メントールグル クロン酸

42. 緒方 章, 介上岩雄：薬誌，58，94〜99（1938） ステリン系に属するホルモンに関する研觉（第 1 報）7Oxo-- $\Delta^{5}$-androsten-3,17-dioldiacetat に就て 
43. 緒方 章, 田中時楌：薬誌，58，111 116 (1938) 甲状腺ホルモン検定に必要なる小動物の炭酸排泄量測定 装置に関する一考案並びに正常動物の炭酸排泄量に就て

44. 緒方 章, 平野四郎, 近鶴次郎 : 薬誌, 58, 315 318 (1938) 男性ホルモンの研究 (第 8 報) 男性ホルモン 作用增強物質汇就て（其 1 )

45. 緒方 章, 田中時彦: 薬誌, 58, 467 480（1938） Dijodotyrosin の生体に対する作用に就て（其 3) 形態 変化，体重，窒素代謝，炭酸排泄量に及添す影響並びにアセトニトリル中毒に対する抵抗力增進 作用

46. 平野四郎, 山野井良作：薬誌，58，580～582（1938）男性ホルモンの研究（第 9 報）牞牛血液, 豚摂護腺及 び精亭中の男性ホルモン

47. 平野四郎, 平沢金太郎 : 薬誌, 58, 583 586（1938）男性ホルモンの研究（第10報）雞畉黄中の性ホルモン 飞就て (其 1 )

48. 緒方 章, 川上岩雄: 薬誌, $58,738 \sim 742$ (1938) ステリン系に属するホルモンに関する研究（第 2 報） $\alpha, \beta$-不飽和-Keton 飞対する知見

49. 緒方 章, 森 文苗 : 薬誌，58，859～870（1938）解熱剤としての地龍の成分研究（第 1 報）

50. 緒方 章, 平野四郎, 佐藤武雄 : 薬誌, 59, 110 113 (1939) 赤蜻蛉成分の研究予報

51. 緒方 章, 川上岩雄 : 薬誌, 59, 439 442 (1939) 男性ホルモンの研究（第11報）男性ホルモン作用增強物 質に就て（其 2)

52. 緒方 章, 毛利元鑑, 森 文苗 : 薬誌, 59, 483 494 (1939) 解熱剂としての地龍の成分研究 (第 2 報)

53. 緒方 章, 湊 顕 : 薬誌, 60, 191 204 (1940) 海亀油成分の研究（第 4 報）

54. 緒方 章, 高木敬次郎: 薬誌, 61, 209 213 (1941) 赤蛙蛤成分の研究（第 1 報）

55. 緒方 章, 湊 顕 : 薬誌, 61, 213 216 (1941) 海亀油成分の研究（第 2 報）

56. 緒方 章, 金子太郎：薬誌，62，55６1（1942）薬品（駆虫薬）としての石灰藻の応用研究（予報）虹蚓及 び豚蜔虫に対する石灰藻の毒性試験並びに蛔虫寄生豚に対する石灰藻による駆虫予試験

57. 緒方 章, 湊 顕 : 薬誌, 62, 106 119 (1942) 海亀油成分の研究（第 3 報）

58. 湊 顕 : 薬誌, 62， 119 129（1942）海亀油の研究（第 4 報）海亀油の経皮吸収に就て

59. 緒方 章, 新延信吉 : 薬誌, 62，152 160 (1942) 局所麻酥性を有するアミノ化合体の研究 (第 2 報) 第 1 級 Diphenylalkylamin の局所麻酰性飞就て

60. 緒方 章, 新延信吉: 薬誌, 62，160１62（1942）局所麻酔性学有するアミノ化合体の研究（第 3 報） Hydrobenzhydrylamin の局所麻轱性飞就て

61. 緒方 章, 新延信吉 : 薬誌, 62，372 375 (1942) Homobenzhydrylamin の局所麻醉性に就て

62. 緒方 章, 田中時彦: 薬誌, 63，67 75（1943）解熱剤としての地龍の成分研究（第 3 報）(付アミノ酸の発 熱動物汇対する解熱作用)

63. 新延信吉 : 薬誌，63，204 211 (1943) 局所麻酥性を有するアミノ化合体の研究（第 5 報）第 1 級アルキル アミン及び第 1 級モノフェニルアルキルアミンに就て並びに第 1 級アミノ化合体の構造と局所麻 酥作用との関係流て

64. 緒方 章, 高木敬次郎, 水谷 彰: 薬誌, 63, 412 416 (1943) 中枢性鎮垓作用を有する化合体の生物学的 試験装置飞就て

65. 緒方 章, 野崎泰彦: 酥誌，63，416〜425（1943）グルクロン酸のナフトレン゙ルチン反応に杼いて生ずる色 素に就て

66. 緒方 章, 伊藤四十二 : 薬誌, 63，477 488（1943）男性ホルモンの研究（第12報）男性ホルモン作用增強 性物質の研究（其 3)

67. 緒方 章, 菰田太郎: 薬誌 63，653〜658 (1943) 八スノハカシパソ (Echinarachinius mirabilis) の成分 飞就て

68. 緒方 章, 伊藤四十二, 岡部佐七: 薬誌，64，79 88 (1944) 睡液腺ホルモンの研究（第 1 報）

69. 緒方 章, 伊藤四十二：野崎泰彦，岡部佐七：薬誌，64，114 126 (1944) 嶓液腺ホルモンの研究(第 2 報) 
70. 緒方 章, 金子太郎：薬誌，64，246２53 (1944) 化学療法剤としての Naphthalin 系化合体の研究（其 1) 駆虫薬の研究

71. 野崎泰彦 : 薬誌, 64, 乙42〜43（甲 9 10) (1944) グルクロン酸のナフトレゾルチン反応において生ずる色 素に就て

72. 野崎 泰彦：薬誌，64，乙60６2（甲14～15）（1944）グルクロン酸のナフトレゾルチン反応に搔いて生ず る色素流て

73. 緒方 章, 伊藤四十二：薬誌，64，乙146１53（甲31～32）（1944）唾液腺ホルモンの研究（第 3 報）家鬼 血清カルシウム量低下作用による効力検定法（其 1 )

74. 緒方 章, 伊藤四十二, 水谷 彰: 薬誌, 64，乙325～331（甲60～61）（1944）唓液腺ホルモンの研究（第 4 報）牛耳下腺より有效部分の分離に就て

75. 緒方 章, 伊藤四十二：薬誌，64，乙332３36（甲61～62）（1944）目液腺ホルモンの研究（第５報）家免 血清カルシウム量低下作用による効力検定法（其 2 )

76. 緒方 章, 伊藤四十二，水谷 彰：薬誌，64，乙337～340（甲62～63）（1944）睡液腺ホルモンの研㭝（第 6 報）哽液中の画液腺ホルモン（其 2 )

77. 緒方 章, 伊藤四十二, 水谷 彰, 坂口康治 : 薬誌, 65, 乙9１3 (甲 $3 \sim 4$ ) (1945) 唾液腺ホルモンの研 究 (第 7 報) 牛耳下腺より分離せる有効成分 ( $\mathrm{pH} 5.4$ 沈殿) の性質 (其 1 )

78. 緒方 章, 伊藤四十二, 水谷 彰, 坂口康治：薬誌，65，乙20２6（甲 6 7) (1945) 唾液腺ホルモンの 研究（第 8 報）牛耳下腺より分離せる有効成分（pH 5.4 沈殿）の性質（其 2 )

79. 緒方 章, 伊藤四十二, 水谷 彰: 薬誌, 65, 乙27〜31（甲 7〜8） (1945)

80. 緒方 章, 伊藤四十二, 行方正也：薬誌，65，乙32３5（甲 9 10) (1945) 唾液腺ホルモンの研究（第10 報）牛耳下腺の有效等電点沈殿部分とリポイド部分との関係

81. 緒方 章, 伊藤四十二, 水谷 彰：薬誌，65，乙36４2（甲10～11） (1945) 陲液腺ホルモンの研究（第11 報）牛耳下腺水浸液をエーテルにて抽出したる場合のエーテル可溶性リポイド部分と蛋白質部分 との效力の比較

82. 伊藤四十二 : 薬誌, 65, 乙43４7（甲11～13) (1945) 囯液腺ホルモンの研究（第12報）牛耳下腺の有効不鹼 化部分と pH 5.4 沈殿との関係並びに唾液腺ホルモンの化学的本態に関する考察

83. 緒方 竟, 高木敬次郎, 水谷 彰: 薬誌, 66, 乙102 111 (甲44) (1946) 昆虫の黒焼成分飞就て（第 1 報) 赤蜻蛉の黒焼

94. 緒方 章, 高木敬次郎, 水谷 彰, 飯島重男 : 薬誌, 66, 乙111 115（甲45４6) (1946) 昆虫の黒焼成分に 就て (第 2 報) 蝗虫の黑焼

85. 緒方 章, 金子太郎 : 薬誌, 67, 25 28 (1947) ナフタリン系化合体の医薬品としての応用研究（第 2 報） 駆虫薬としての研究（其 2)

86. 緒方 章, 金子太郎 : 薬誌, 67, 29 32 (1947) ナフタリン系化合体の医薬品としての応用研究（第 3 報） (其 2 ), 抗マラリア剂としての研究

87. 高取吉太郎 : 薬誌, 67，191～192（1947）スルフォンアミド剤合成の研究（第1報）ロダン系ズルフォンア ミドの合成（其 1 )

88. 新延信吉 : 薬誌， 67，250 252（1947）局所麻酔性を有するアミノ化合体の研究（第6 報） 4-Aminobenzyl- $\beta$-phenäthylamin系化合体飞就て

89. 高木敬次郎 : 薬誌, 68, 115 121 (1948) 昆虫の黑焼成分（第 3 報）

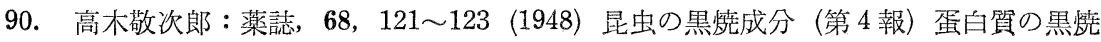

